Research Paper

\title{
Establishment of an Inflamed Animal Model of Diabetic Nephropathy
}

\author{
Kun Ling $\mathrm{Ma}^{1}{ }^{凶}$, Yang Zhang${ }^{1}$, Jing $\mathrm{Liu}^{1}{ }^{1}, \mathrm{Yu} \mathrm{Wu}^{1}$, Ze Bo Hu${ }^{1}$, Xiong Zhong Ruan², Bi Cheng Liu${ }^{1}$ \\ 1. Institute of Nephrology, Zhong Da Hospital, Southeast University School of Medicine, Nanjing City, Jiangsu Province, China. \\ 2. Centre for Nephrology, University College London (UCL) Medical School, Royal Free Campus, UK.
}

\begin{abstract}
$\square$ Corresponding author: Kun Ling Ma, Institute of Nephrology, Zhong Da Hospital, Southeast University School of Medicine, NO.87, Ding Jia Qiao Road, Nanjing City, Jiangsu Province, China, 210009. Tel: 008625 83262442; Fax 00862583262442 ; E-mail: mmkk11@hotmail.com

() Ivyspring International Publisher. This is an open-access article distributed under the terms of the Creative Commons License (http://creativecommons.org/ licenses/by-nc-nd/3.0/). Reproduction is permitted for personal, noncommercial use, provided that the article is in whole, unmodified, and properly cited.
\end{abstract}

Received: 2013.10.13; Accepted: 2014.01.06; Published: 2014.01.18

\begin{abstract}
Aims Inflammatory stress plays a crucial role in the progression of diabetic nephropathy (DN). This study aimed to establish a novel inflamed animal model of DN and to evaluate its significance in DN.

Methods Nondiabetic $\mathrm{db} / \mathrm{m}$ mice and diabetic $\mathrm{db} / \mathrm{db}$ mice were randomly divided into four groups: $d b / m, d b / m+c a s e i n, d b / d b$, and $d b / d b+c a s e i n$ for eight weeks. Casein was subcutaneously injected to induce chronic inflammation. Body weight and albumin to creatinine ratio (ACR) in the urine were measured every week. The plasma levels of serum amyloid protein A (SAA) and tumour necrotic factor- $\alpha$ (TNF- $\alpha$ ) were determined with the enzyme-linked immunosorbent assay. The morphological changes to the renal pathology and ultra-microstructures were checked by pathological staining and electron microscopy. Immunofluorescent staining and Western blotting were used to determine the protein expression of podocyte-specific molecules and inflammatory cytokines in kidneys.
\end{abstract}

Results ACR, plasma levels of SAA and TNF- $\alpha$, protein expression of inflammatory cytokines, mesangial expansion, collagen accumulation, and foot process effacement in kidneys of casein-injected $\mathrm{db} / \mathrm{db}$ mice were significantly increased compared with the $\mathrm{db} / \mathrm{db}$ mice. Casein injection markedly decreased the protein expression of Wilms' tumor-I and nephrin in kidneys of $\mathrm{db} / \mathrm{db}$ mice, which are specific podocyte biomarkers, suggesting that chronic inflammation accelerates podocyte injuries in $\mathrm{db} / \mathrm{db}$ mice. Interestingly, no obvious urinary protein, inflammatory cytokine expression, or histological changes in the kidneys of casein-injected $\mathrm{db} / \mathrm{m}$ mice were found compared with the $\mathrm{db} / \mathrm{m}$ mice.

Conclusion An inflamed animal model of DN was successfully established and may provide a useful tool for investigating the pathogenesis of DN under inflammatory stress.

Key words: Diabetic nephropathy, inflammation, $\mathrm{db} / \mathrm{db}$ mice, animal model

\section{Introduction}

Diabetic nephropathy (DN) is a common and serious microvascular complication of diabetes mellitus that remains the foremost cause of end-stage renal disease (ESRD) in Western countries (1). Unfortunately, the mechanisms leading to the development and progression of DN have not been completely elu- cidated. Therefore, it is very important to identify new pathogenic pathways that provide more opportunities for early diagnosis and therapy.

Chronic inflammation has been recognised as a key player in the pathogenesis of DN. Several lines of evidence from experimental and clinical studies have 
demonstrated the participation of various inflammatory molecules and pathways in the setting of $\mathrm{DN}$, such as acute phase reactants, inflammatory cytokines, adhesion molecules, and chemokines, which are activated by the metabolic, biochemical, and haemodynamic derangements known to exist in the diabetic kidney (2). These inflammatory pathways lead to the activation and recruitment of macrophages and fibroblasts, which in turn initiate and sustain renal injury and fibrotic repair processes $(3,4)$. Apart from the conventional control of blood glucose and blood pressure, targeting the specific pathways that lead to the activation of inflammation and the recruitment of fibroblasts could be a new and effective intervention in the management of DN. However, from a therapeutic perspective, only limited experience is available regarding the inhibition of inflammatory cytokines in DN. Therefore, further experimentation and clinical trials are necessary to examine the potential mechanisms of inflammation in aggravating DN.

An animal model is a useful tool for researchers to clarify the role of chronic inflammation in the pathogenesis of DN. At present, there are a variety of animal models used to study $\mathrm{DN}$, including $\mathrm{db} / \mathrm{db}$ mice, ob/ob mice, Otsuka Long-Evans Tokushima Fatty (OLETF) rats, and streptozotocin-induced rats. However, currently, there is no inflamed DN animal model for the investigation of the potential mechanisms of chronic inflammation in the progression of DN. Therefore, this study aimed to establish a novel inflamed DN animal model and to evaluate its significance in the research field of $\mathrm{DN}$.

\section{Materials and methods}

\section{Animal model}

$\mathrm{db} / \mathrm{m}$ mice and $\mathrm{db} / \mathrm{db}$ mice, which were obtained from the Mode Animal Centre of Nanjing University (Nanjing, China), with a C57BL/KsJ genetic background, were studied using protocols approved by the Ethical Committee of Southeast University, following the latest version of the Declaration of Helsinki. Eight-week-old male nondiabetic $\mathrm{db} / \mathrm{m}$ and diabetic $\mathrm{db} / \mathrm{db}$ mice were randomly divided into four groups and subcutaneously injected every other day with $0.5 \mathrm{ml}$ distilled water or $0.5 \mathrm{ml} 10 \%$ casein $(n=10$ for each group): $d b / m, d b / m+$ casein, $d b / d b$, and $d b / d b+$ casein mice. The mice were fed with $a$ normal chow diet containing $4 \%$ fat for eight weeks. Individual mice were placed in metabolic cages for 24-hour urine collection. At the end of the experimental period, blood samples were obtained from the right ventricle for the biochemical assays, and kidney samples were used for histological assessments.

\section{Enzyme-linked immunosorbent assay}

The serum levels of serum amyloid protein A (SAA, Invitrogen, USA) and tumour necrotic factor- $\alpha$ (TNF- $\alpha$, R\&D, USA) were measured by kits.

\section{Biochemical assays}

After the experimental period, the mice were euthanised, and blood samples were obtained from the right ventricle for biochemical analysis. The concentrations of blood glucose (BG), blood urea nitrogen (BUN), serum creatinine (Scr), triglyceride (TG), total cholesterol (TC), high-density lipoprotein (HDL) and low-density lipoprotein (LDL) were determined by automatic analysers (Hitachi, Japan). Albumin to creatinine ratio (ACR) was calculated by analysing the results of albumin and creatinine in the urine determined by enzyme-linked immunosorbent assay and clinical biochemistry assay.

\section{Morphological analysis}

Kidneys were either fixed in $10 \%$ buffered formalin and embedded in paraffin (light microscopy) or fixed in $2.5 \%$ glutaraldehyde and embedded in Lowicryl K4M resin (electron microscopy). Further procedures included periodic acid-Schiff (PAS) staining, trichrome-masson staining, and transmission electron microscopy.

\section{Immunohistochemical staining}

After deparaffinisation, sections were placed in citrate-buffered solution ( $\mathrm{pH}$ 6.0) and heated for antigen retrieval. Subsequently, the sections were incubated with anti-mouse primary antibodies of TNF- $\alpha$ and MCP-1(Santa Cruz, USA) overnight at $4^{\circ} \mathrm{C}$, followed by incubation with biotinylated secondary antibodies. Finally, a diaminobenzidine tetrahydrochloride substrate was used to develop the reaction. The results were observed under a light microscope $(\times 400)$.

\section{Immunofluorescent staining}

The kidney sections were fixed with $4 \%$ paraformaldehyde and blocked in PBS containing 5\% BSA (bovine serum albumin) for 60 minutes. The anti-mouse primary antibodies of a rabbit polyclonal antibody against Wilms' tumor-1 (WT-1) (Santa Cruz, USA) and a goat polyclonal antibody against nephrin (Santa Cruz, USA) were added and incubated overnight at $4^{\circ} \mathrm{C}$. After a wash with PBS (pH 7.2), the sections were incubated with donkey anti-rabbit Fluor 555 and donkey anti-goat Fluor 488 secondary fluorescent antibodies (Invitrogen, USA), respectively. After washing, the slides were examined by laser confocal microscopy $(\times 400)$. 


\section{Western blotting}

Equal amounts of total proteins from the homogenates of partial kidney tissues in mice were separated by sodium dodecyl sulphate polyacrylamide gel electrophoresis. The membranes were blocked with blocking buffer for 1 hour at room temperature after gel transfer. The membranes were then incubated with anti-mouse primary antibodies, MCP-1, TNF- $\alpha$, WT-1, or nephrin (Santa Cruz, USA), overnight at $4^{\circ} \mathrm{C}$, followed by incubation with horseradish peroxidase-labelled secondary antibodies for 2 hours. Finally, signals were detected using enhanced chemiluminescence (GE Healthcare, USA).

\section{Statistical analysis}

All of the data are expressed as the means \pm standard deviation (SD) and processed with the SPSS software 13.0. Continuous variables were compared between the two groups with an independent-sample $t$ test (where appropriate). A difference was considered significant if the $P$ value was less than 0.05 .

\section{Results}

\section{Basic biochemical data in four groups of mice}

As shown in Table 1, there were significant decrease in Ccr and increases in BG, TG, TC, and Scr in $\mathrm{db} / \mathrm{db}$ mice and $\mathrm{db} / \mathrm{db}+$ casein mice compared with $\mathrm{db} / \mathrm{m}$ mice and $\mathrm{db} / \mathrm{m}+$ casein mice $(\mathrm{P}<0.05)$. In addition, although there was a similar body weight in $\mathrm{db} / \mathrm{db}$ mice and $\mathrm{db} / \mathrm{db}+$ casein mice at the beginning of the experiments, the casein-injected $\mathrm{db} / \mathrm{db}$ mice showed a decreased body weight from the third week compared with $\mathrm{db} / \mathrm{db}$ mice (Fig. 1).

Table I. Basic biochemical data in the four groups of mice.

\begin{tabular}{lllll}
\hline parameters & $\mathrm{db} / \mathrm{m}$ & $\mathrm{db} / \mathrm{m}+$ casein & $\mathrm{db} / \mathrm{db}$ & $\mathrm{db} / \mathrm{db}+\mathrm{casein}$ \\
\hline BG $(\mathrm{mmol} / \mathrm{l})$ & $12.88 \pm 1.73$ & $12.33 \pm 1.34$ & $46.47 \pm 3.90^{*}$ & $52.42 \pm 4.30^{* *}$ \\
$\mathrm{TG}(\mathrm{mmol} / \mathrm{l})$ & $0.87 \pm 0.05$ & $0.81 \pm 0.08$ & $1.22 \pm 0.27^{*}$ & $1.17 \pm 0.29^{*}$ \\
$\mathrm{TC}(\mathrm{mmol} / \mathrm{l})$ & $2.45 \pm 0.12$ & $2.53 \pm 0.32$ & $3.36 \pm 0.17^{*}$ & $3.32 \pm 0.13^{*}$ \\
LDL $(\mathrm{mmol} / \mathrm{l})$ & $0.81 \pm 0.06$ & $1.34 \pm 0.12$ & $1.03 \pm 0.09$ & $1.37 \pm 0.11$ \\
HDL $(\mathrm{mmol} / \mathrm{l})$ & $1.71 \pm 0.28$ & $1.66 \pm 0.02$ & $1.58 \pm 0.18$ & $1.23 \pm 0.09$ \\
BUN (mmol/l) & $10.16 \pm 0.88$ & $10.90 \pm 1.40$ & $11.70 \pm 1.10$ & $13.70 \pm 5.33$ \\
SCr $(\mathrm{mmol} / \mathrm{l})$ & $14.00 \pm 2.19$ & $13.67 \pm 2.30$ & $17.33 \pm 2.31^{*}$ & $24.00 \pm 6.93^{* *}$ \\
C cr $(\mathrm{ml} / \mathrm{min})$ & $0.501 \pm 0.032$ & $0.491 \pm 0.028$ & $0.387 \pm 0.053^{*}$ & $0.250 \pm 0.025^{* *}$
\end{tabular}

Eight-week-old male nondiabetic $\mathrm{db} / \mathrm{m}$ and diabetic $\mathrm{db} / \mathrm{db}$ mice were randomly divided into four groups and subcutaneously injected with once-two-day 0.5 of ml distilled water or $0.5 \mathrm{ml}$ of $10 \%$ casein $(\mathrm{n}=10): \mathrm{db} / \mathrm{m}, \mathrm{db} / \mathrm{m}+$ casein, $\mathrm{db} / \mathrm{db}$, and $\mathrm{db} / \mathrm{db}+$ casein mice. The mice were fed with a normal chow diet containing $4 \%$ fat for eight weeks. BG: blood glucose, TG: triglyceride, TC: total cholesterol, LDL: low-density lipoprotein. HDL: high-density lipoprotein, BUN: blood urea nitrogen, SCr: serum creatinine. Ccr: creatinine clearance rate. Ccr: creatinine clearance rate. Values were represented as the means $\pm \mathrm{SD},{ }^{*} P<0.05 \mathrm{vs}$. $\mathrm{db} / \mathrm{m}$ group, ${ }^{* *} P<0.01$ vs. $\mathrm{db} / \mathrm{db}$ group.

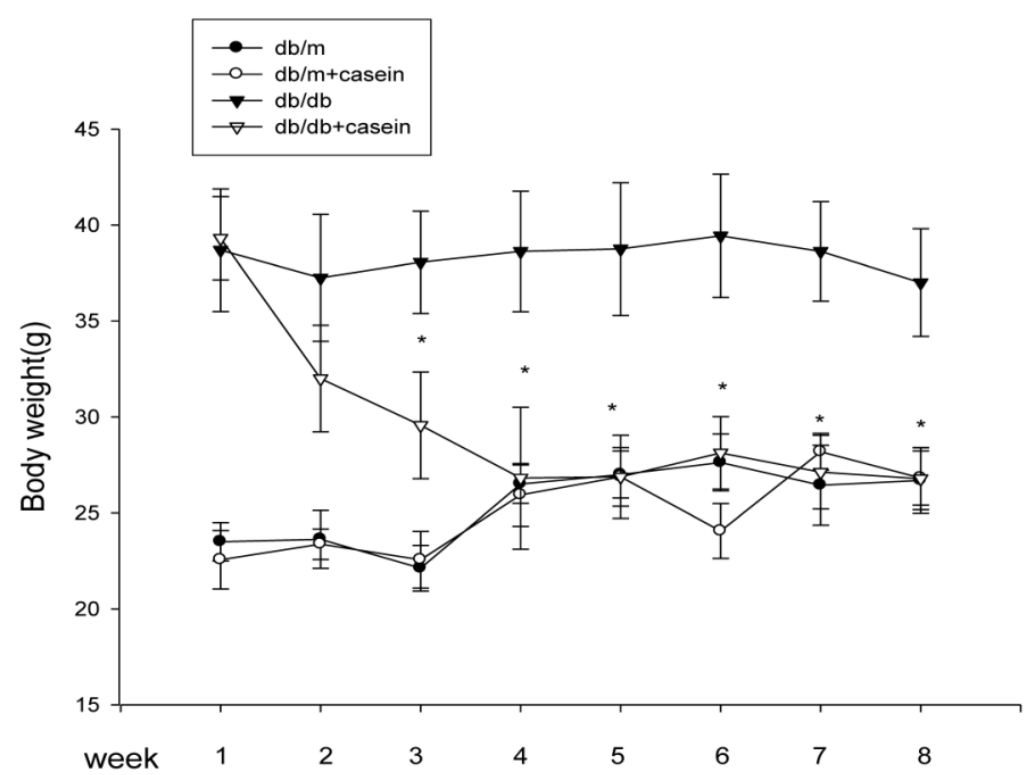

Fig. I The body weight changes in four groups of mice. Eight-week-old male nondiabetic $\mathrm{db} / \mathrm{m}$ and diabetic $\mathrm{db} / \mathrm{db}$ mice were randomly divided into four groups and subcutaneously injected with every other day $0.5 \mathrm{ml}$ of distilled water or $0.5 \mathrm{ml}$ of $10 \%$ casein $(\mathrm{n}=10$ for each group): $\mathrm{db} / \mathrm{m}, \mathrm{db} / \mathrm{m}+\mathrm{casein}$, $\mathrm{db} / \mathrm{db}$, and $\mathrm{db} / \mathrm{db}+$ casein mice. The mice were fed with a normal chow diet containing $4 \%$ fat for eight weeks. The body weight changes were measured at each week. Values were represented as the means $\pm S D * P<0.01 \mathrm{vs}$. $\mathrm{db} / \mathrm{db}$ group. 
A

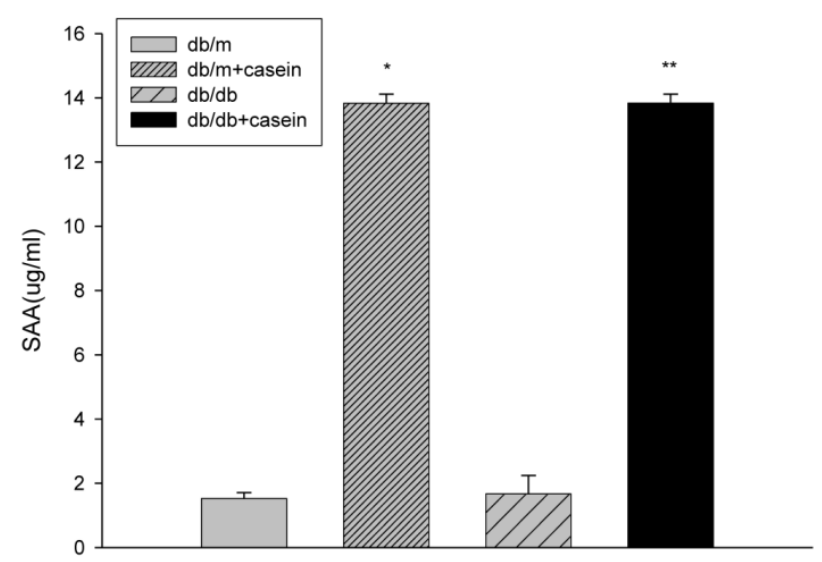

B

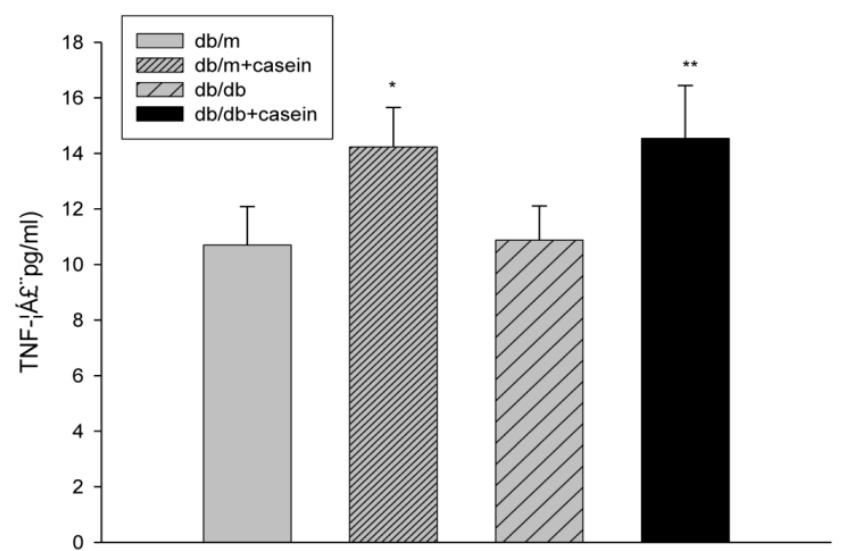

Fig. 2 The production of inflammatory cytokines in four groups of mice. Eight-week-old male nondiabetic $\mathrm{db} / \mathrm{m}$ and diabetic $\mathrm{db} / \mathrm{db}$ mice were randomly divided into four groups and subcutaneously injected with every other day $0.5 \mathrm{ml}$ of distilled water or $0.5 \mathrm{ml}$ of $10 \%$ casein $(n=10$ for each group): $d b / m, d b / m+$ casein, $d b / d b$, and $d b / d b+c a s e i n$ mice. The mice were fed with a normal chow diet containing $4 \%$ fat for eight weeks ( $A$ and $B$ ). At the end of the experimental period, the levels of SAA and TNF- $\alpha$ in the serum were measured by ELISA. Values were represented as the means $\pm S D * P<0.01$ vs. $d b / m$ group, $* * P<0.01$ vs. $d b / d b$ group.

\section{Establishment of the inflamed DN mouse model}

Our results demonstrated that the serum levels of SAA and TNF-a were both significantly increased in casein-injected $\mathrm{db} / \mathrm{m}$ mice and $\mathrm{db} / \mathrm{db}$ mice, compared with the controls (Fig. 2). Furthermore, we checked the protein expression of TNF- $\alpha$ and MCP-1 in the kidneys of mice. Immunohistochemistry and Western blotting analysis showed that there was increased protein expression of TNF- $a$ and MCP-1 in the kidneys of $d b / d b$ mice compared with $d b / m$ mice (Fig. 3A-3C). Interestingly, casein injection exacer- bated the protein expression of TNF- $\alpha$ and MCP-1 in the kidneys of $\mathrm{db} / \mathrm{db}$ mice, whereas there was no difference in the kidneys of $\mathrm{db} / \mathrm{m}$ mice, regardless of the status of casein injection. In order to exclude the effects of infiltrated macrophages on the protein expression of TNF- $\alpha$ and MCP-1 in the kidneys of casein injected $\mathrm{db} / \mathrm{db}$ mice, CD68 protein expression was checked by immunohistochemical staining. Results showed that there was no difference for CD68 protein expression between casein injected $\mathrm{db} / \mathrm{db}$ and $\mathrm{db} / \mathrm{db}$ mice (Fig.3D-3E).

\section{Inflammation increased proteinuria and exacerbated histopathological damage to the kidney in $\mathrm{db} / \mathrm{db}$ mice}

As shown in Fig. 4, ACR was progressively elevated in $\mathrm{db} / \mathrm{db}$ mice from the fourth week. Interestingly, there was heavier excretion of urinary microalbumin in casein-injected $\mathrm{db} / \mathrm{db}$ mice than in $\mathrm{db} / \mathrm{db}$ mice from the fourth week. We further observed histopathological changes in the kidneys under inflammatory stress. PAS staining and Trichrome-masson staining demonstrated that glomerular hypercellularity, mesangial expansion, and collagen depositions were significantly increased in the kidneys of $d b / d b$ mice compared with those of $\mathrm{db} / \mathrm{m}$ mice (Fig. 5A-5D). Furthermore, casein injection deteriorates these changes in the kidneys of $\mathrm{db} / \mathrm{db}$ mice. Transmission electron microscopy analysis showed that casein-injected $\mathrm{db} / \mathrm{db}$ mice have a more significant degree of thickened glomerular basement membrane (GBM) mesangial expansion, and podocyte foot process fusion than $\mathrm{db} / \mathrm{db}$ mice (Fig. 5E). These findings suggested that chronic inflammation accelerated the progression of glomerulosclerosis in the $\mathrm{db} / \mathrm{db}$ mice. However, the casein-injected $\mathrm{db} / \mathrm{m}$ mice showed no obvious change.

\section{Inflammation induced podocyte injuries in kidneys of $d b / d b$ mice}

WT-1 and nephrin are specific biomarkers of podocytes. As demonstrated by immunofluorescent staining, inflammatory stress significantly decreased the protein expression of WT-1 and nephrin in kidneys of casein-injected $\mathrm{db} / \mathrm{db}$ mice compared with $\mathrm{db} / \mathrm{db}$ mice, suggesting that inflammatory stress plays an important role in the deterioration of podocyte injuries in DN (Fig. 6A). Western blotting analysis showed that inflammation markedly downregulated the protein expression of nephrin in the kidneys of casein-injected $\mathrm{db} / \mathrm{db}$ mice compared with $\mathrm{db} / \mathrm{db}$ mice (Fig. 6B and 6C), which was in accordance with the results from immunofluorescent staining. 
A

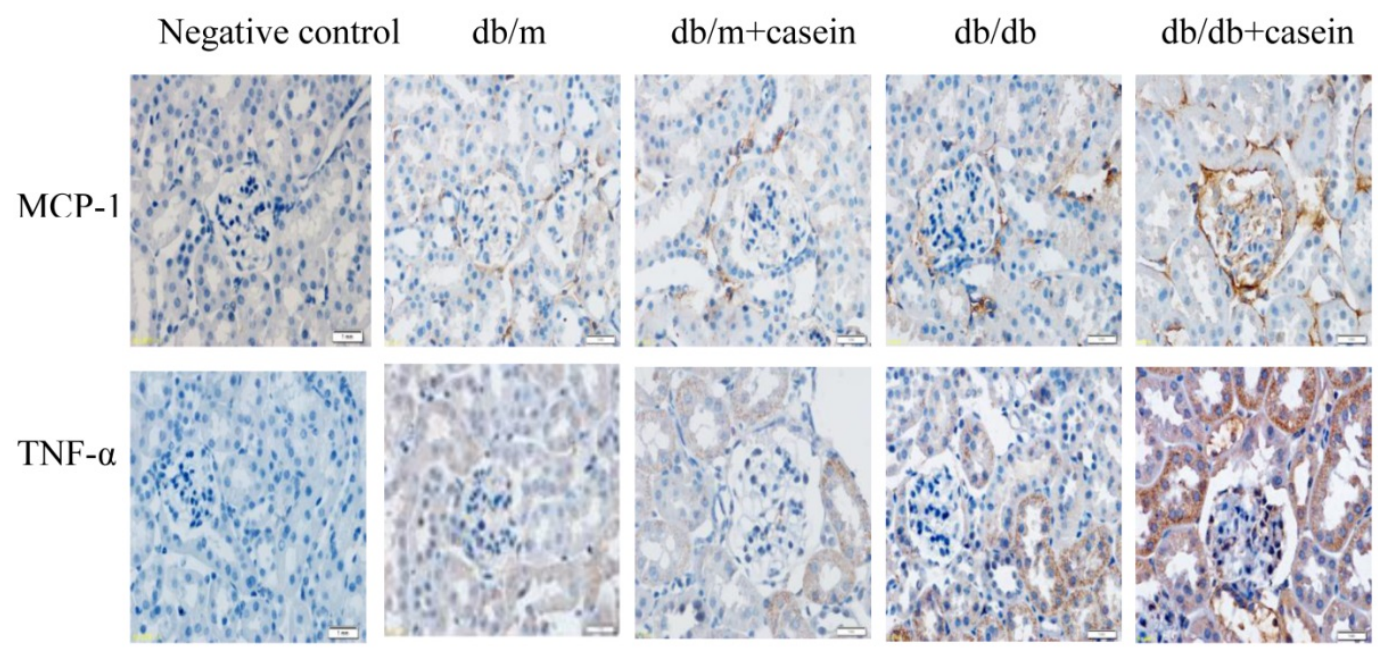

B

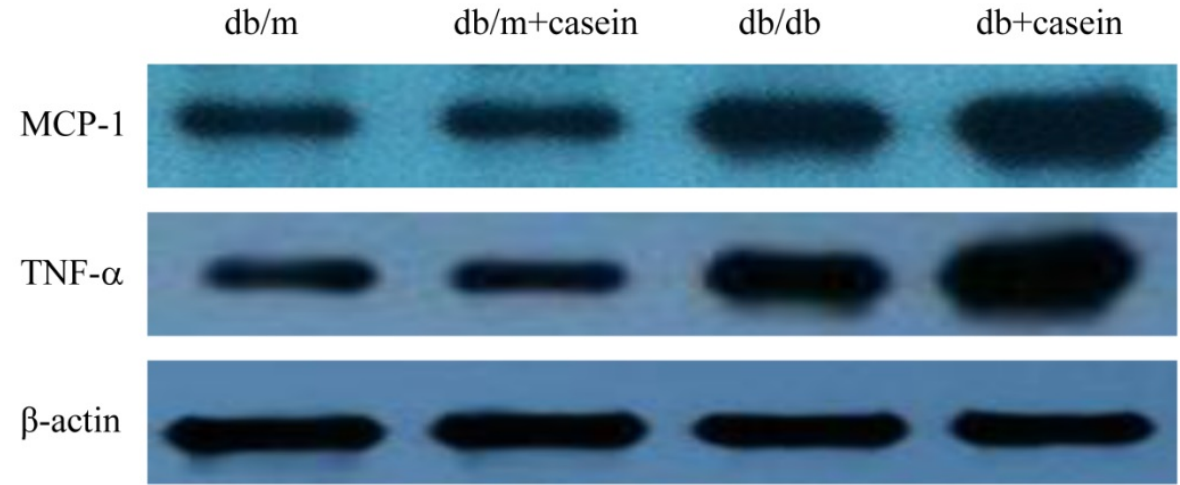

12KDa

C

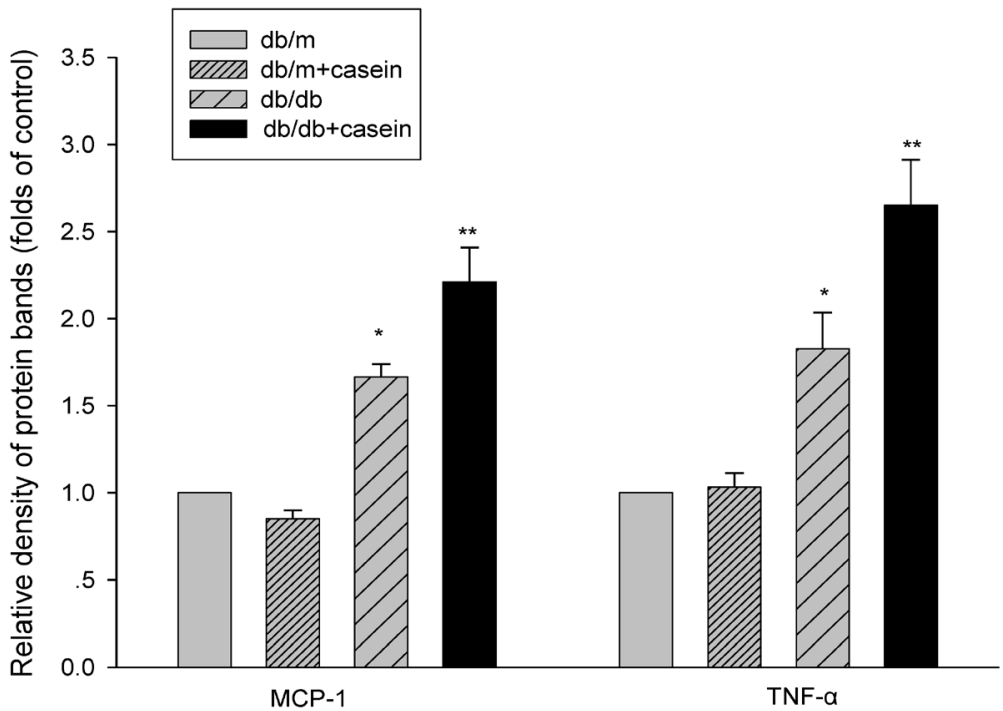

42KDa 
D.

$\mathrm{db} / \mathrm{m}$

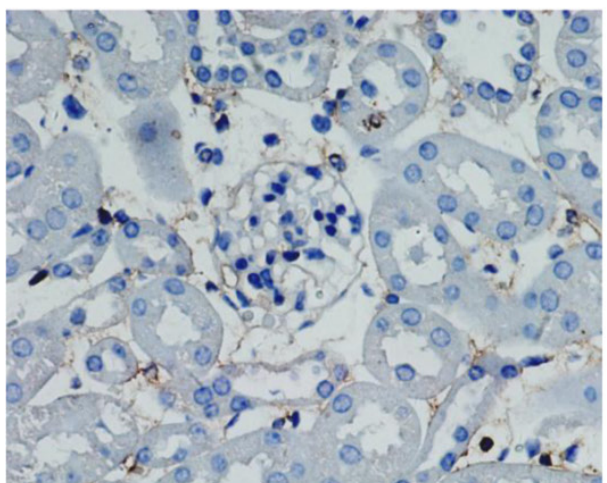

$\mathrm{db} / \mathrm{db}$

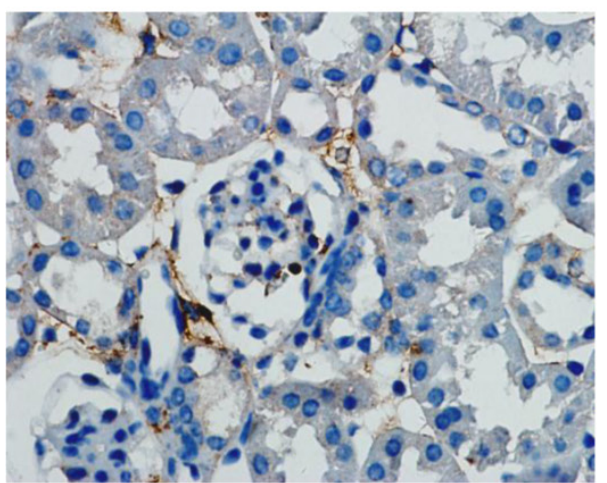

$\mathrm{db} / \mathrm{m}+$ casein

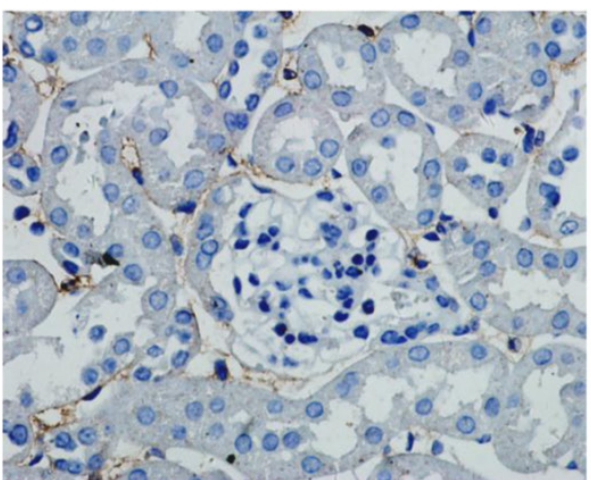

$\mathrm{db} / \mathrm{db}+$ casein

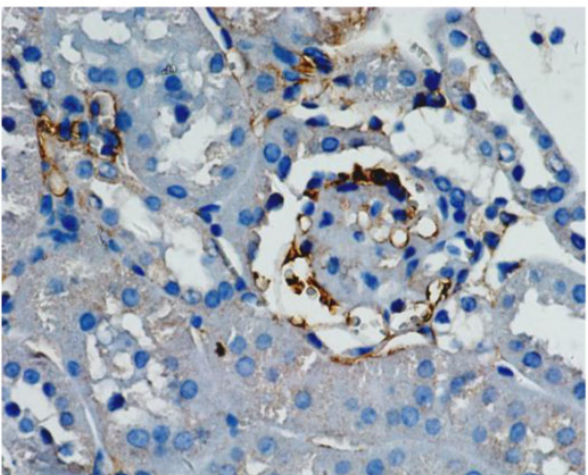

E.

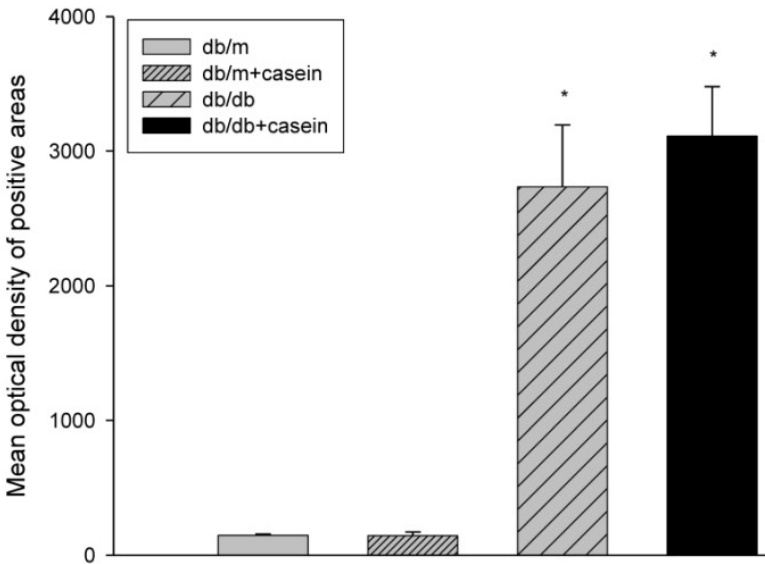

Fig. 3 Inflammation increased the protein expression of inflammatory cytokines in the kidneys of db/db mice. Eight-week-old male nondiabetic $\mathrm{db} / \mathrm{m}$ and diabetic $\mathrm{db} / \mathrm{db}$ mice were randomly divided into four groups and subcutaneously injected with every other day $0.5 \mathrm{ml}$ of distilled water or $0.5 \mathrm{ml}$ of $10 \%$ casein ( $\mathrm{n}=10$ for each group): $\mathrm{db} / \mathrm{m}, \mathrm{db} / \mathrm{m}+$ casein, $\mathrm{db} / \mathrm{db}$, and db/db+casein mice. The mice were fed with a normal chow diet containing $4 \%$ fat for eight weeks. The protein expression of TNF- $\alpha$ and MCP-I in the kidneys of the mice were measured by immunohistochemical staining (A, brown colour, original magnification $\times 400$ ) and Western blotting (B). The histogram represents the means \pm SD of the densitometric scans of the protein bands from the mice per group, normalised by comparison with $\beta$-actin. $* P<0.01 \mathrm{vs}$. $\mathrm{db} / \mathrm{m}$ group, $* * P<0.0 \mathrm{l}$ vs. db/db group $(C)$. The protein expression of CD68 in the kidneys of the mice was measured by immunohistochemical staining. The positive areas were stained brown in cross-sections of kidneys ( $D$, original magnification, $\times 400$ ). The values of semiquantitative analysis for the positive areas were expressed as the mean $\pm S D(n=10$ for each group). There was no difference among four groups. $* P<0.0 \mathrm{I} v \mathrm{v}$. $\mathrm{db} / \mathrm{m}$ group $(\mathrm{E})$. 


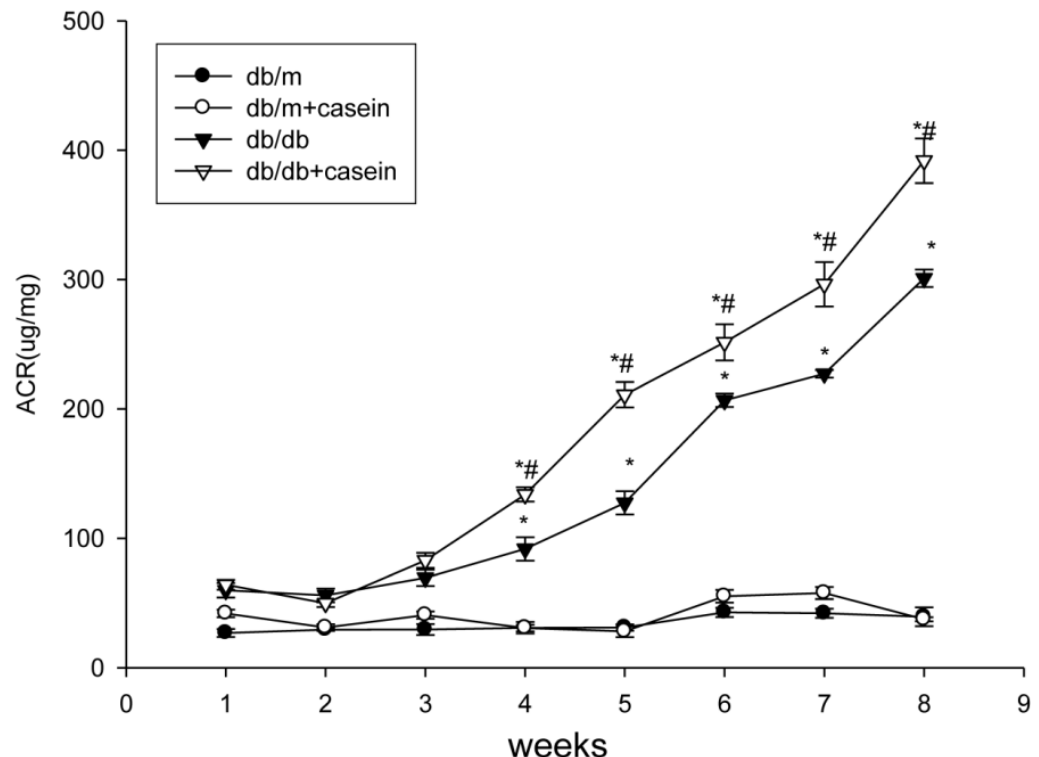

Fig. 4 Inflammation increased the excretion of urinary microalmubin in $\mathbf{d b} / \mathbf{d b}$ mice. Eight-week-old male nondiabetic $\mathrm{db} / \mathrm{m}$ and diabetic $\mathrm{db} / \mathrm{db}$ mice were randomly divided into four groups and subcutaneously injected with every other day $0.5 \mathrm{ml}$ of distilled water or $0.5 \mathrm{ml}$ of $10 \%$ casein $(\mathrm{n}=10$ for each group): $\mathrm{db} / \mathrm{m}, \mathrm{db} / \mathrm{m}+\mathrm{casein}, \mathrm{db} / \mathrm{db}$, and $\mathrm{db} / \mathrm{db}+$ casein mice. The mice were fed with a normal chow diet containing $4 \%$ fat for eight weeks. Albumin to creatinine ratio (ACR) was determined at each week in the mice. Values were represented as the means $\pm \mathrm{SD}$. $* P<0.05 \mathrm{vs}$. $\mathrm{db} / \mathrm{m}$ group, $\# P<0.05 \mathrm{vs} \mathrm{db} / \mathrm{db}$ group.

A

$\mathrm{db} / \mathrm{m}$

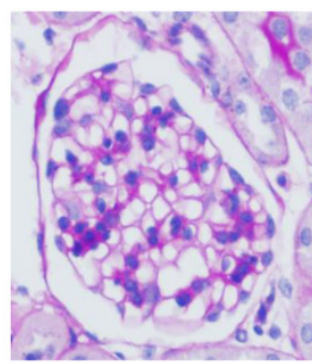

$\mathrm{db} / \mathrm{m}+$ casein

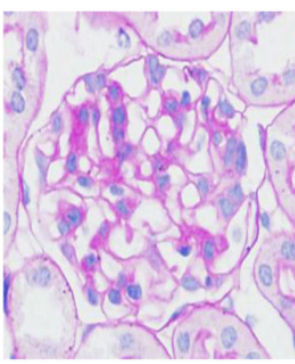

$\mathrm{db} / \mathrm{db}$

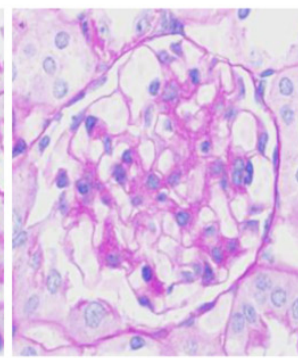

$\mathrm{db}+$ casein

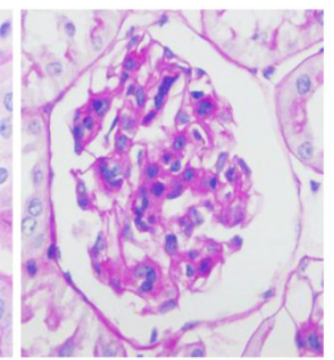

B

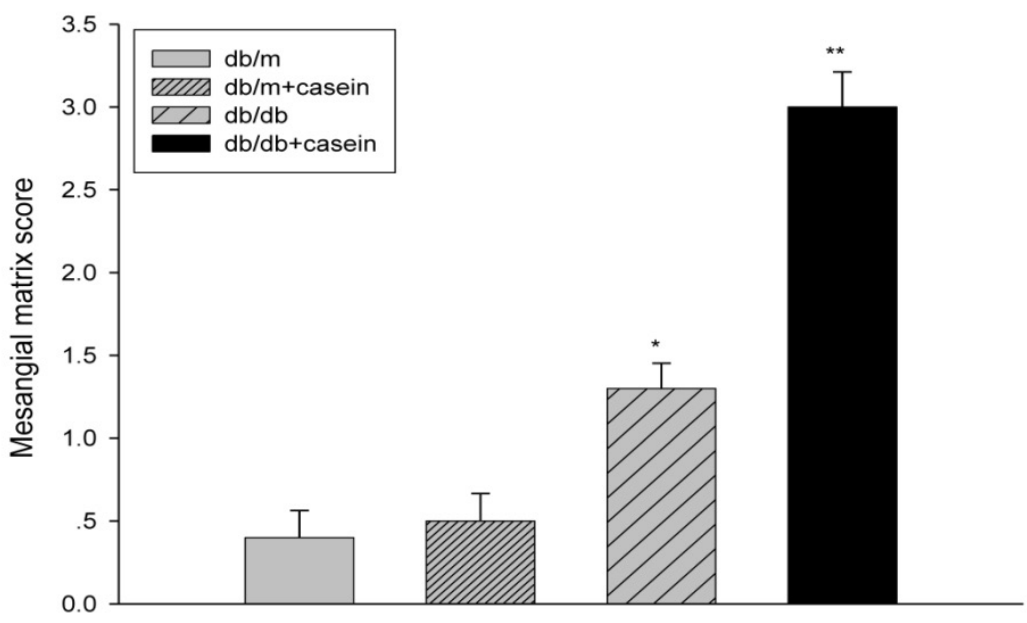


C

$\mathrm{db} / \mathrm{m}$

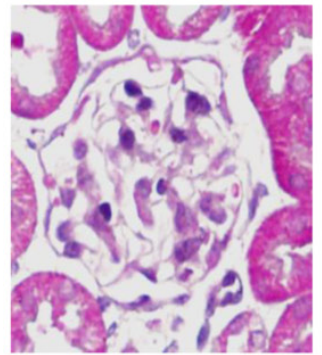

$\mathrm{db} / \mathrm{m}+$ casein

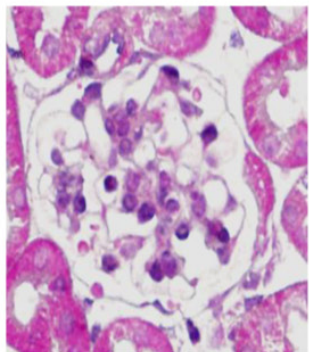

$\mathrm{db} / \mathrm{db}$

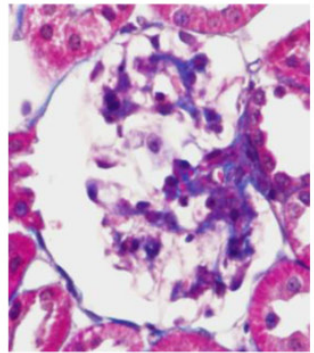

$\mathrm{db}+$ casein

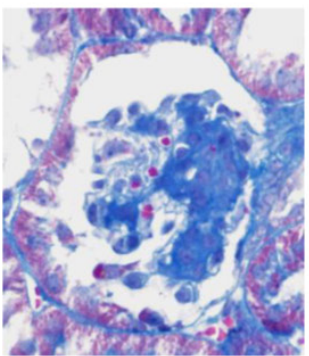

D

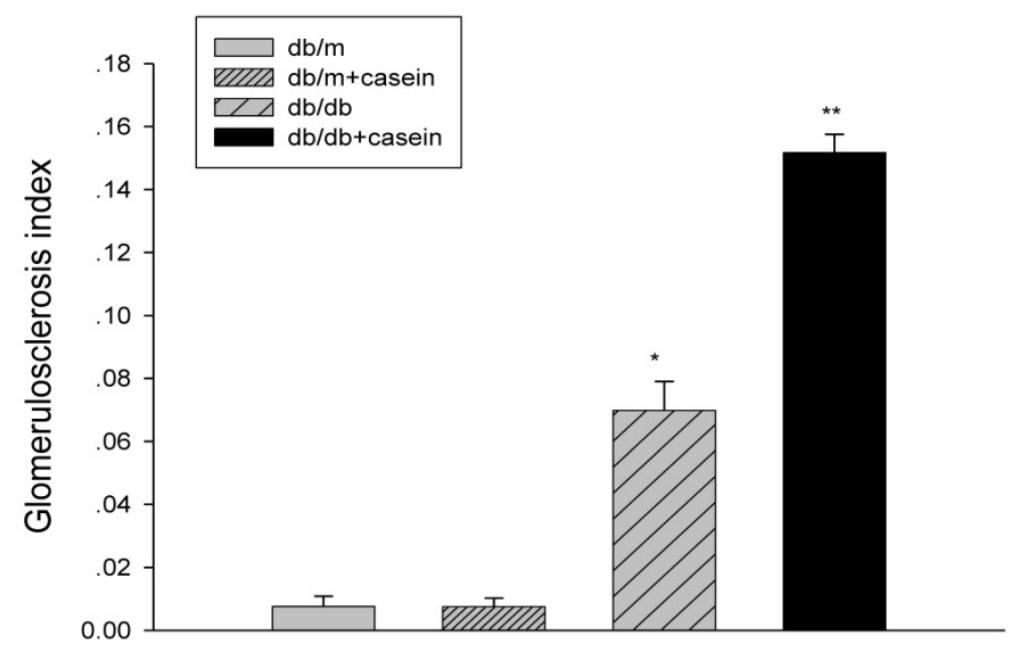

E

$\mathrm{db} / \mathrm{m}$
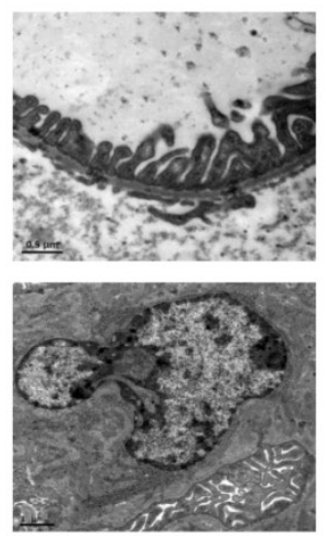

$\mathrm{db} / \mathrm{m}+$ casein
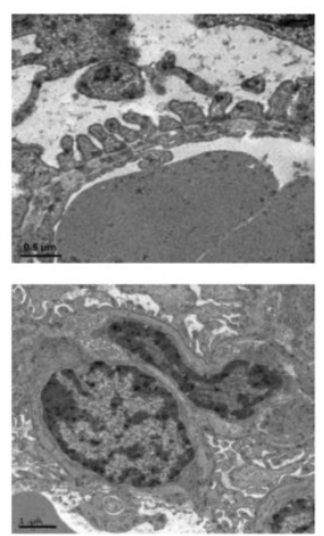

$\mathrm{db} / \mathrm{db}$
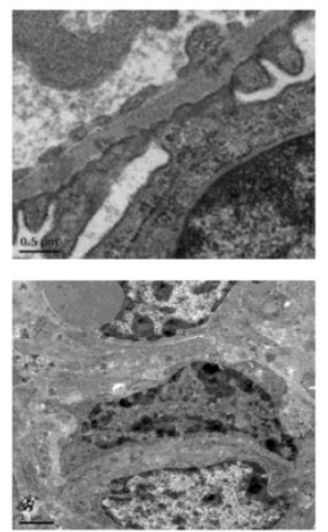

$\mathrm{db} / \mathrm{db}+$ casein
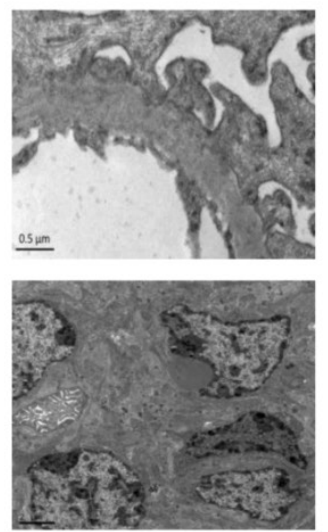

Fig. 5 Inflammation exacerbated the histopathological damage in the kidneys of $\mathbf{d b} / \mathbf{d b}$ mice. Eight-week-old male nondiabetic $\mathrm{db} / \mathrm{m}$ and diabetic $\mathrm{db} / \mathrm{db}$ mice were randomly divided into four groups and subcutaneously injected with every other day 0.5 of $\mathrm{ml}$ distilled water or $0.5 \mathrm{ml}$ of $10 \%$

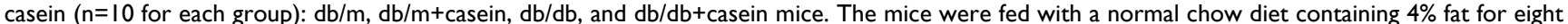
weeks. The histopathological changes were assessed by PAS staining (A and B, red colour, original magnification $\times 400)$ and Masson's trichrome (C and D, blue colour, original magnification $\times 400$ ). The values of semiquantitative analysis for the positive areas are expressed as the means \pm SD from mice at each group. $* P<0.01$ vs. $\mathrm{db} / \mathrm{m}$ group, $* * P<0.05 \mathrm{vs}$. db/db group. The change in the glomerular ultramicrostructure was checked by electromicroscopy $(E)$. 
A

$\mathrm{db} / \mathrm{m}$

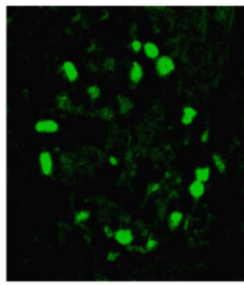

WT-1

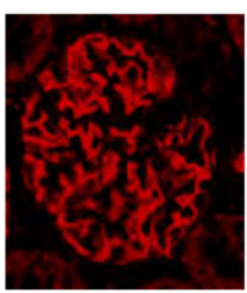

$\mathrm{db} / \mathrm{m}+$ casein
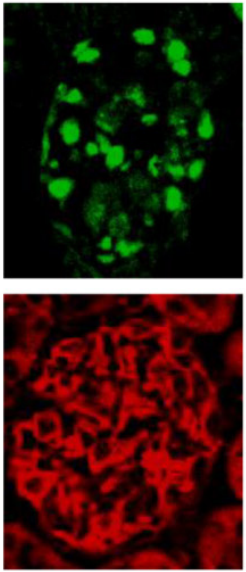

$\mathrm{db} / \mathrm{db}$
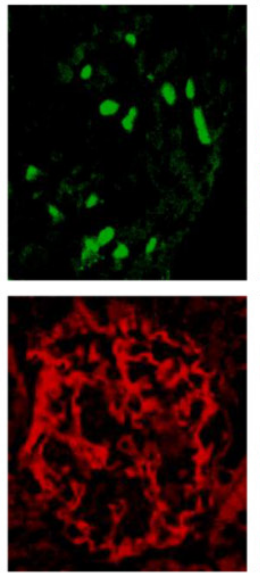

$\mathrm{db}+$ casein
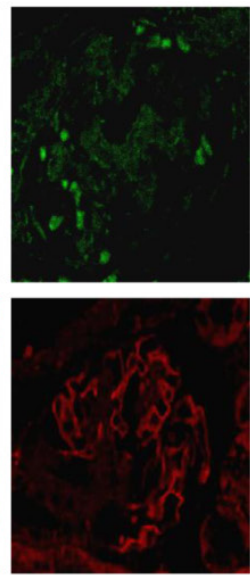

B
$\mathrm{db} / \mathrm{m}$
$\mathrm{db} / \mathrm{m}+$ casein
$\mathrm{db} / \mathrm{db}$
$\mathrm{db} / \mathrm{db}+$ casein
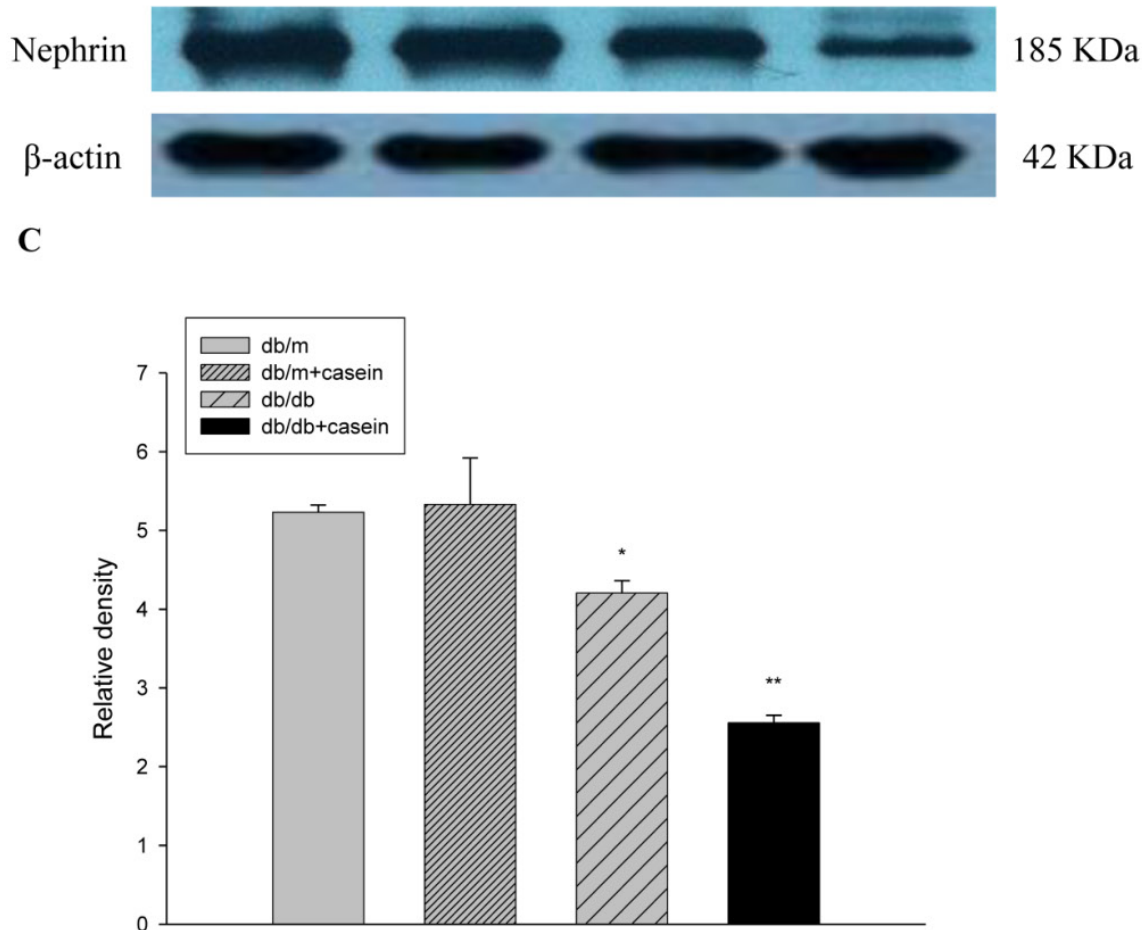

Fig. 6 Inflammation exacerbated podocyte injury in the kidneys of $\mathbf{d b} / \mathbf{d b}$ mice. Eight-week-old male nondiabetic $\mathrm{db} / \mathrm{m}$ and diabetic $\mathrm{db} / \mathrm{db} \mathrm{mice}$ were randomly divided into four groups and subcutaneously injected with every other day $0.5 \mathrm{mof}$ mistilled water or 0.5 of $\mathrm{ml} 10 \%$ casein $(\mathrm{n}=10$ for each group): $\mathrm{db} / \mathrm{m}, \mathrm{db} / \mathrm{m}+$ casein, $\mathrm{db} / \mathrm{db}$, and $\mathrm{db} / \mathrm{db}+$ casein mice. The mice were fed with a normal chow diet containing $4 \%$ fat for eight weeks. The protein expression of WT-I and nephrin were measured by immunofluorescent staining (A, brown colour, original magnification $\times 400)$ and Western blotting (B). The histogram represented means $\pm S D$ of the densitometric scans of the protein bands from mice, normalised by comparison with $\beta$-actin. $* P<0.01$ vs. $\mathrm{db} / \mathrm{m}$ group, $* * P<0.05 \mathrm{vs}$. $\mathrm{db} / \mathrm{db}$ group $(\mathrm{C})$.

\section{Discussion}

DN is chronic inflammatory disease (5). The inflammation and activation of the immune system is closely associated with the development and progression of DN (6-8), which is different from traditional infectious inflammations characterised by swelling, redness, pain and fever. This type of inflammation, which is activated by metabolic, biochemical, and haemodynamic disorders, is described as chronic, low-grade 'meta-flammation' (metabolically triggered inflammation) (9) and contributes to persistent kidney injuries and DN progression. Therefore, clarifying the mechanisms of the inflam- 
matory signal pathways involved in $\mathrm{DN}$ and preventing the progression of kidney injuries represent an enormous challenge for the researcher. However, currently, there is no reliable inflamed DN animal model. This study aimed to establish an inflamed DN animal model using $\mathrm{db} / \mathrm{db}$ mice.

In our previous studies, we successfully established an inflamed animal model of non-alcoholic fatty liver disease using apolipoprotein E knockout mice fed with a Western diet and subcutaneously injected with $10 \%$ casein (10). Casein, a protein extracted from milk, has often been used to induce chronic inflammation in recent years (10-13). The mechanism for casein-induced inflammation is not clear but could be correlated with the activation of the immune system and increased synthesis of liver acute-phase reactants. In this study, using $\mathrm{db} / \mathrm{db}$ mice, a widely used type 2 diabetic model, we attempted to establish an inflamed DN model by subcutaneously injecting $10 \%$ casein. The $\mathrm{db} / \mathrm{db}$ mouse, lacking the hypothalamic leptin receptor, is a model of type 2 diabetes mellitus that exhibits hyperglycaemia, hyperinsulinaemia, and hyperleptinaemia associated with the hyperphagia and obesity that manifest at 4-7 weeks after birth $(14,15)$. The results of our pilot show that there was a high mortality rate in mice in conditions of daily casein injection, which was correlated with local skin infection and sudden death. However, when mice were treated with every other day casein injections, the mortality rate decreased to a very low level over the whole experimental period. Our results showed that the serum levels of SAA and TNF- $\alpha$, both in casein-injected $\mathrm{db} / \mathrm{m}$ mice and casein-injected $\mathrm{db} / \mathrm{db}$ mice, were significantly increased, suggesting that systemic inflammation had successfully been induced. Interestingly, although the serum levels of inflammatory cytokines in casein-injected $\mathrm{db} / \mathrm{m}$ mice were increased, the expression of inflammatory cytokines and histopathological changes of kidneys did not differ between casein-injected $\mathrm{db} / \mathrm{m}$ mice and $\mathrm{db} / \mathrm{m}$ mice. The CD68 protein expression in kidneys of diabetic mice was higher than that in non-diabetic mice, however, which was no difference between casein injected $d b / d b$ mice and $d b / d b$ mice, suggesting that the production of inflammatory cytokines in kidneys of casein injected $\mathrm{db} / \mathrm{db}$ mice was not caused by infiltrated macrophages. Chronic inflammation aggravated the progression of kidney injuries in DN. From the fifth week on, there was a more significant proteinuria in casein-injected $\mathrm{db} / \mathrm{db}$ mice compared with $\mathrm{db} / \mathrm{db}$ mice, which was in accordance with the more marked protein expression of inflammatory cytokines, mesangial matrix expansion, and collagen deposition in the kidneys of casein-injected $\mathrm{db} / \mathrm{db}$ mice compared with $\mathrm{db} / \mathrm{db}$ mice. These findings suggested that chronic inflammation deteriorated the progression of DN and shortened the whole experimental period. This means that the intensity of the inflammation in casein-injected DN mice was higher than the intensity of the meta-flammation in $\mathrm{DN}$ mice alone, allowing for the observation of kidney injuries in $\mathrm{DN}$ using casein-injected $\mathrm{db} / \mathrm{db}$ mice over a shorter experimental period and thus satisfying a rudimental requirement as a stable animal model.

We further assessed the effects of chronic inflammation on podocyte injuries in $\mathrm{db} / \mathrm{db}$ mice. Our results demonstrated that chronic inflammation exacerbated podocyte injury, shown with the more significant effacement of podocyte foot processes, podocyte loss, and dysfunction of the slit diaphragm. The protein expression of WT-1 and nephrin, both specific biomarkers of podocytes, was significantly decreased in casein-injected $\mathrm{db} / \mathrm{db}$ mice compared with $\mathrm{db} / \mathrm{db}$ mice. These results, together with those of previous studies (16-18), confirmed that inflammation was a key player in accelerating the development and progression of DN. The subcutaneous casein injection was safe and effective in the induction of an inflamed DN animal model and the deterioration of podocyte injuries in DN.

In conclusion, we successfully established an inflamed DN animal model. The kidney injuries of inflamed DN mice resembled the pathological changes of DN mice alone, whereas the intensity of inflammation and the degree of kidney injuries in inflamed DN mice were higher and more significant. Furthermore, the establishment of this inflamed DN animal model could be a useful tool for studying and understanding the mechanisms of inflammatory signal pathways in the progression of $\mathrm{DN}$.

\section{Acknowledgement}

This work was supported by Grants 81170792 and 81070571 from the National Natural Science Foundation of China.

\section{Competing Interests}

The authors have declared that no competing interest exists.

\section{References}

1. Ritz E, Rychlik I, Locatelli F, Halimi S. End-stage renal failure in type 2 diabetes: A medical catastrophe of worldwide dimensions. Am J Kidney Dis 1999; 34(5):795-808.

2. Lim AK, Tesch GH. Inflammation in diabetic nephropathy. Mediators Inflamm 2012; 2012:146154.

3. Duffield JS. Macrophages and immunologic inflammation of the kidney. Semin Nephrol 2010; 30(3):234-254.

4. Ricardo SD, van GH, Eddy AA. Macrophage diversity in renal injury and repair. J Clin Invest 2008; 118(11):3522-3530.

5. Nguyen DV, Shaw LC, Grant MB. Inflammation in the pathogenesis of microvascular complications in diabetes. Front Endocrinol (Lausanne) 2012; 3:170.

6. Festa A, D'Agostino R, Jr., Howard G, Mykkanen L, Tracy RP, Haffner SM. Chronic subclinical inflammation as part of the insulin resistance syndrome: 
the Insulin Resistance Atherosclerosis Study (IRAS). Circulation 2000; 102(1):42-47.

7. Frohlich M, Imhof A, Berg G, Hutchinson WL, Pepys MB, Boeing H, et al. Association between C-reactive protein and features of the metabolic syndrome: a population-based study. Diabetes Care 2000; 23(12):1835-1839.

8. Pickup JC, Mattock MB, Chusney GD, Burt D. NIDDM as a disease of the innate immune system: association of acute-phase reactants and interleukin-6 with metabolic syndrome X. Diabetologia 1997; 40(11):1286-1292.

9. Hotamisligil GS. Inflammation and metabolic disorders. Nature 2006; 444(7121):860-867.

10. Ma KL, Ruan XZ, Powis SH, Chen Y, Moorhead JF, Varghese Z. Inflammatory stress exacerbates lipid accumulation in hepatic cells and fatty livers of apolipoprotein E knockout mice. Hepatology 2008; 48(3):770-781.

11. Kang SB, Kim HM, Kim HJ, Seok H, Huh JH, Lee BW, et al. Rosiglitazone attenuates casein-induced hepatic endoplasmic reticulum stress in Sprague-Dawley rats: a novel model of endoplasmic reticulum stress. Endocr J 2013 Aug 20.

12. Ma KL, Liu J, Wang CX, Ni J, Zhang $Y, W u ~ Y$, et al. Activation of mTOR modulates SREBP-2 to induce foam cell formation through increased retinoblastoma protein phosphorylation. Cardiovasc Res 2013 Sep 25.

13. Xu ZE, Chen Y, Huang A, Varghese Z, Moorhead JF, Yan F, et al. Inflammatory stress exacerbates lipid-mediated renal injury in ApoE/CD36/SRA triple knockout mice. Am J Physiol Renal Physiol 2011; 301(4):F713-F722.

14. Breyer MD, Bottinger E, Brosius FC III, Coffman TM, Harris RC, Heilig CW, et al. Mouse models of diabetic nephropathy. J Am Soc Nephrol 2005; 16(1):27-45.

15. King AJ. The use of animal models in diabetes research. Br J Pharmacol 2012; 166(3):877-894

16. Du P, Fan B, Han H, Zhen J, Shang J, Wang X, et al. NOD2 promotes renal injury by exacerbating inflammation and podocyte insulin resistance in diabetic nephropathy. Kidney Int 2013; 84(2):265-276.

17. Fornoni A, Ijaz A, Tejada $\mathrm{T}$, Lenz $\mathrm{O}$. Role of inflammation in diabetic nephropathy. Curr Diabetes Rev 2008; 4(1):10-17.

18. Xing Y, Ye S, Hu Y, Chen Y. Podocyte as a potential target of inflammation: role of pioglitazone hydrochloride in patients with type 2 diabetes. Endocr Pract 2012; 18(4):493-498 